\title{
A FORMULA FOR CALCULATING THE EFFECTS OF FEEDING ON THE IODINE NUMBER OF MILK FAT
}

\author{
Pellervo SaArinen and Marita Lönnfors 1 \\ Department of Animal Husbandry, University of Helsinki
}

Received February 2, 1956

It is a well known fact that a very close relationship exists between the iodine number of milk fat and the consistency of butter $(19,39,33,32)$. To overcome defects in the consistency of the butter the iodine number of the butter fat should be c. $32-37(33,4,23)$.

It has long been established that the iodine number of milk fat is influenced especially by the fat in the ration, but the exact nature of this effect is still somewhat obscure. There are, however, several facts which may help substantially in predicting the possible effect of a ration on the iodine number of the milk fat produced.

In the first place, the effect depends on the amount of fat in the ration. A low fat diet consisting of large amounts of root crops, tops or leaves, beet pulp, potato or by-products, barley, wheat, rye, peas etc. usually results in a low iodine number apparently due to the fact that comparatively a very small amount of the unsaturated fatty acids is formed from carbohydrates and protein $(20,38,40,41,42,7,25)$.

Secondly, feeding more fat results either in increased or decreased iodine numbers in milk fat depending on the degree of unsaturation of the fat in feed $(7,20,27)$. Pasture grass, which is relatively rich in fat with an iodine number of appreciably over 100 , results in soft butter fat with a relatively high iodine number $(24,10,15)$. AIV-fodder and well preserved silage may have a similar effect $(40,36$, $45,15,12)$. Linseeds (flax seeds), soybeans, rape seeds, sesam seeds, sunflower seeds, fish meal, ground nuts, corn, wheat bran, oats etc. relatively rich in unsaturated fats and oils also produce soft butter $(22,20,43,40,41,42,44,6,16,9,1,31,34$, $24,30,17,11,2,26,14)$.

Pressed oil cakes show a less clear increasing effect than oil seeds, and low fat solvent extracted oil meals may show an opposite effect $(20,40,41,42)$.

1) The experimental data in this paper are taken in part from a thesis presented by Marita Lönnfors in partial fulfillment of the requirements for the degree of M. Sc. Agr. in animal husbandry, Univ. of Helsinki. 
Feeding hay in which the unsaturated fatty acids are oxidized usually results in hard butter with a low iodine number $(41,15)$.

Feedstuffs rich in saturated fats, such as coconut and palm kernel cakes, decrease the iodine number of milk fat $(20,21,41,7,1)$.

In brief, the amount of the digestible unsaturated fatty acids in the ration is apparently one of the principal factors affecting the iodine number of milk fat.

A second factor relating to the iodine number of milk fat is energy underfeeding. This factor is commonly active at the beginning of the lactation period, a time at which the cows are often physiologically underfed. A relationship between the amount of decrease in the cows' live weight and the iodine number of butter fat produced at the same time has been reported by Jarl (27). Starving has a still more distinct effect (37). The fat mobilized from the depôts during underfeeding undergoes desaturation before being utilized. The amount of unsaturated fat entering the circulation appears to be equivalent to c. $200 \mathrm{~g}$ of oleic acid per every Scandinavian feed unit underfeeding.

At the end of the lactation period the iodine value of milk fat is generally high $(35,3)$. When dealing with Ayrshire cows, Storgårds (41) observed that in otherwise similar conditions the iodine number of the milk fat produced by the low testing animals was higher than in the milk fat produced by the high testing cows. These observations support the view that the third factor effecting the iodine number of milk fat is the total amount of milk fat produced. To express the combined effects of both the amount of the digestible unsaturated fat in the ration and the amount of milk fat produced, Jarl (27) has used a quotient called mrelative iodine number product».

Overfeeding is not considered to influence the iodine number of milk fat $(13,27)$.

Frye et. al. $(16,17,18,3)$ have reported that there also exists a highly significant correlation between the barn temperature and the iodine and the cyanogen numbers of butter fat.

A survey of the literature appears to support the possibility of the assumption that the iodine number of milk fat is a resultant of four factors regulating the ingo and outgo of unsaturated fatty acids, i.e. 1) the amount of digestible unsaturated fatty acids in the ration 2) amount of these acids in the milk fat produced, 3) amount of fat mobilization or storage to the depots and 4) synthesis and destruction of unsaturated fatty acids in the body.

The two feeding trials presented below have been carried out to check the validity of this assumption.

$$
\text { Experimental procedure }
$$

To investigate the effects of feeding on the iodine number of $m$ ' $s$ fat two feeding trials were carried out at the Viiki experimental farm.

In the first trial the main variable was the amount of unsaturated atty acids (U.F.A.) in proportion to the amount of milk fat produced. 
The trial was conducted between $4 / 2$ and 20/5, 1952 with 12 Ay. cows of different size and age. The cows were divided into four fairly equal groups as regards the stage of lactation and pregnancy, milk and fat yield, live weight etc. All animals were fed individually and to begin with according to Poijärvi's standards. The basal ration, which consisted of hay, AIV-fodder and beet pulp, remained unchanged for all the cows and all three experimental periods. The concentrate mixture contained crushed barley and oats, soybean meal, linseed meal plus crushed linseeds heated up to $100-110^{\circ} \mathrm{C}$ before crushing. For one group, standard feeding was used for all these periods. The three remaining groups obtained the same standard feeding during the first and third experimental periods (preliminary and afterperiods) but during the second period (experimental period) one part of the grain mixture was gradually exchanged for crushed linseeds. With this the amount of digestible fat in the ration increased from c. $300 \mathrm{~g}$ to c. $650 \mathrm{~g}$ a day but the amount of feed units and, for two groups, the amount of digestible crude protein too remained unchanged.

A regular feed analysis was made of all the feeds used. A decsription of the feeds, their chemical composition, assumed coefficients of digestibility and the calculated net energy values are presented in table 1.

The cows were fed and milked twice daily. Milking was done by machine. Composite 3-day samples were used to determine the fat content of the milk and the different characteristics of milk fat.

The Gerber procedure was used for determining milk fat. The iodine number of milk fat was determined by using the Hanus technique. The refraction number was determined at $40^{\circ} \mathrm{C}$ using Zeiss's Abbé refractor. In addition the ReichertMeissl and some Polenske values of the milk fat were also determined.

Additional data upon the effect of feeding were calculated during the grazing season and during the period Oct.-Nov. 1952, when sugar beet tops were fed. The results obtained appeared to be fairly distinct and hence another feeding trial was arranged during the stall feeding period 1954-1955.

The second trial, which was conducted between 26th Nov. 1954 and 31st Jan. 1955, included 12 Ay-cows divided into 3 groups. In this experiment the ratio unsaturated fatty acids to the amount of milk fat produced was kept constant, but the other factors under study were varied in turn. The amount of saturated fat in the ration was varied by substituting coconut fat for feed carbohydrates. Different carbohydrates were used for different groups.

The methods of sampling and the analytical procedures used were the same as before. A description of these feeds is presented in table 2 .

The amount of unsaturated fatty acids (U.F.A.) in the ration $\mathrm{g} /$ day was calculated as a "oleic acid equivalent" using the following formula:

U.F.A consumed $\mathrm{g} /$ day $=\frac{282 \cdot \text { Iodine number of feed fat }}{254 \cdot 100} \times$ amount fat in feed, $\mathrm{g} /$ day,

where 282 represents the molecular weight of oleic acid and 254 equals twice the atomic weight of iodine. 
Table 1. Description of the feeds used in the first feeding trial $4 / 2-20 / 51952$

\begin{tabular}{|c|c|c|c|c|c|c|c|c|c|c|c|c|}
\hline \multirow[b]{2}{*}{ Feed } & \multirow{2}{*}{$\begin{array}{c}\begin{array}{c}\text { Dry } \\
\text { matter }\end{array} \\
\\
\%\end{array}$} & \multirow{2}{*}{$\begin{array}{c}\text { Ash } \\
\\
\%\end{array}$} & \multirow[t]{2}{*}{$\begin{array}{l}\text { Crude } \\
\text { protein }\end{array}$} & \multirow{2}{*}{$\begin{array}{c}\text { True A } \\
\text { pro- } \\
\text { tein } \\
\\
\%\end{array}$} & Amids & \multirow[t]{2}{*}{$\begin{array}{c}\text { Crude } \\
\text { fat }\end{array}$} & \multirow[t]{2}{*}{$\begin{array}{l}\mathrm{N} \text {-free } \\
\text { extracts }\end{array}$} & \multicolumn{2}{|l|}{$\begin{array}{c}\text { Crude } \\
\text { fiber. }\end{array}$} & \multicolumn{3}{|c|}{ Calculated } \\
\hline & & & & & 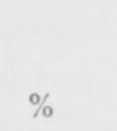 & & & $\%$ & $\begin{array}{l}\text { Sc. feed } \\
\text { units } \\
\text { pro } \\
\mathrm{kg} \text { feed }\end{array}$ & $\begin{array}{c}\text { Dig. } \\
\text { crude } \\
\text { prot. } \\
\%\end{array}$ & $\begin{array}{l}\text { Dig. } \\
\text { fat } \\
\%\end{array}$ & $\begin{array}{c}\text { Iodine } \\
\text { number }\end{array}$ \\
\hline Hay & 78.90 & 6.97 & 9.63 & 7.41 & 2.22 & 1.28 & $3 \quad 40.47$ & 20.55 & $5 \quad 0.49$ & 6.16 & 0.69 & 90 \\
\hline AIV (pasture grass) & 21.70 & 2.53 & 3.16 & 2.22 & 0.94 & 1.08 & 8.48 & 6.44 & $4 \quad 0.14$ & 2.09 & 0.65 & 120 \\
\hline Beet pulp & 7.77 & 0.31 & 0.99 & 0.89 & 0.09 & 0.03 & 4.67 & 1.78 & 8 0.075 & 0.63 & - & - \\
\hline Oats (crushed) & 85.98 & 2.77 & 9.19 & 8.21 & 0.98 & 4.96 & $6 \quad 60.45$ & 8.62 & 20.85 & 7.35 & 4.12 & 102 \\
\hline Barley (crushed) & 86.06 & 2.42 & 10.19 & 9.35 & 0.84 & 1.92 & 67.44 & 4.09 & 1.03 & 7.64 & 1.71 & 113 \\
\hline Soybean oil meal & & & & & & & & & & & & \\
\hline (extracted) & 81.92 & 4.80 & 37.81 & 36.27 & 1.53 & 0.48 & 30.54 & 8.29 & $9 \quad 0.90$ & 34.03 & 0.42 & 130 \\
\hline Linseed cakes & 88.88 & 5.32 & 32.87 & 32.57 & 0.29 & 8.53 & $3 \quad 32.32$ & 9.85 & $5 \quad 1.06$ & 28.60 & 7.68 & 172 \\
\hline Linseeds (fat,crushed) & 92.82 & 3.67 & 22.39 & 21.44 & 0.95 & $5 \quad 37.00$ & 23.14 & 6.62 & $2 \quad 1.71$ & 17.91 & 35.15 & 180 \\
\hline
\end{tabular}

Table 2. Description of the feeds used in the second feeding trial $26 / 11-31 / 11955$

\begin{tabular}{|c|c|c|c|c|c|c|c|c|c|c|c|c|}
\hline \multirow[b]{2}{*}{ Freed } & \multirow{2}{*}{$\begin{array}{c}\text { Dry } \\
\text { matter } \\
\\
\%\end{array}$} & \multirow{2}{*}{$\begin{array}{l}\text { Ash } \\
\% \\
\%\end{array}$} & \multirow{2}{*}{$\begin{array}{c}\text { Crude } \\
\text { pro- } \\
\text { tein }\end{array}$} & \multirow{2}{*}{$\begin{array}{c}\text { True } \\
\text { pro- } \\
\text { tein }\end{array}$} & \multirow{2}{*}{$\begin{array}{c}\text { Amids } \\
\%\end{array}$} & \multirow{2}{*}{$\begin{array}{c}\text { Crude } \\
\text { fat } \\
\\
\%\end{array}$} & \multirow{2}{*}{$\begin{array}{c}\text { N-free } \\
\text { extracts } \\
\\
\%\end{array}$} & \multirow{2}{*}{$\begin{array}{c}\text { Crude } \\
\text { fiber } \\
\\
\%\end{array}$} & \multicolumn{4}{|c|}{ Calculated } \\
\hline & & & & & & & & & $\begin{array}{l}\text { Sc. feed } \\
\text { units } \\
\text { pro } \\
\mathrm{kg} \text { feed }\end{array}$ & $\begin{array}{l}\text { Dig. } \\
\text { crude } \\
\text { prot. } \\
\%\end{array}$ & $\begin{array}{c}\text { Dig. } \\
\text { crude } \\
\text { fat } \\
\%\end{array}$ & $\begin{array}{l}\text { Iodine } \\
\text { number }\end{array}$ \\
\hline Hay & 78.4 & 6.91 & 8.51 & 7.28 & 1.23 & 2.21 & 33.28 & 27.49 & 0.40 & 5.19 & 1.13 & 90 \\
\hline AIV & 23.9 & 1.90 & 4.32 & 3.83 & 30.48 & 1.06 & 9.28 & 7.34 & 0.17 & 3.32 & 0.62 & $2 \quad 120$ \\
\hline Beet pulp (dried) & 81.8 & 3.70 & 8.50 & 7.20 & 1.30 & - & 52.60 & 16.50 & 0.81 & 4.70 & - & - \\
\hline Oats (crushed) & 88.7 & 3.19 & 10.36 & 9.93 & 0.44 & 4.79 & 61.20 & 9.14 & 0.89 & 8.28 & 3.97 & $\begin{array}{ll}7 & 102\end{array}$ \\
\hline Wheat bran & 88.4 & 5.60 & 15.90 & 14.00 & 1.90 & 4.20 & 54.90 & 7.80 & 0.85 & 13.80 & 3.49 & $9 \quad 120$ \\
\hline Soybean (expellers) & 87.1 & 5.21 & 42.63 & 41.20 & 1.43 & 5.75 & 26.91 & 6.60 & 0.98 & 38.79 & 2.82 & $2 \quad 130$ \\
\hline Peanut cake & 90.9 & 5.72 & 50.28 & 46.08 & 2.20 & 6.90 & 13.74 & 4.78 & 1.00 & 44.74 & 6.21 & 93 \\
\hline Linseeds (crushed) & 98.8 & 4.00 & 25.80 & 24.30 & 1.50 & 38.90 & 24.30 & 5.80 & 1.81 & 20.60 & 37.00 & 180 \\
\hline Coconut fat & 100.0 & - & - & - & - & 100.0 & - & - & - & - & - & 8.6 \\
\hline
\end{tabular}

Except in the milk fat samples the iodine number was determined only in the linseed fat and coconut fat. For the other feed fats the average values found in the literature $(5,21,39,41)$ were used, because these values appear to vary less than the resorption of different unsaturated fatty acids, which was not determined. The iodine numbers used in the calculations are included in tables 1 and 2 .

\section{Results}

Among the factors presented above the amount of U.F.A. in the ration and the amount of milk fat secreted or the ratio

U.F.A. consumed

M.F. secreted 


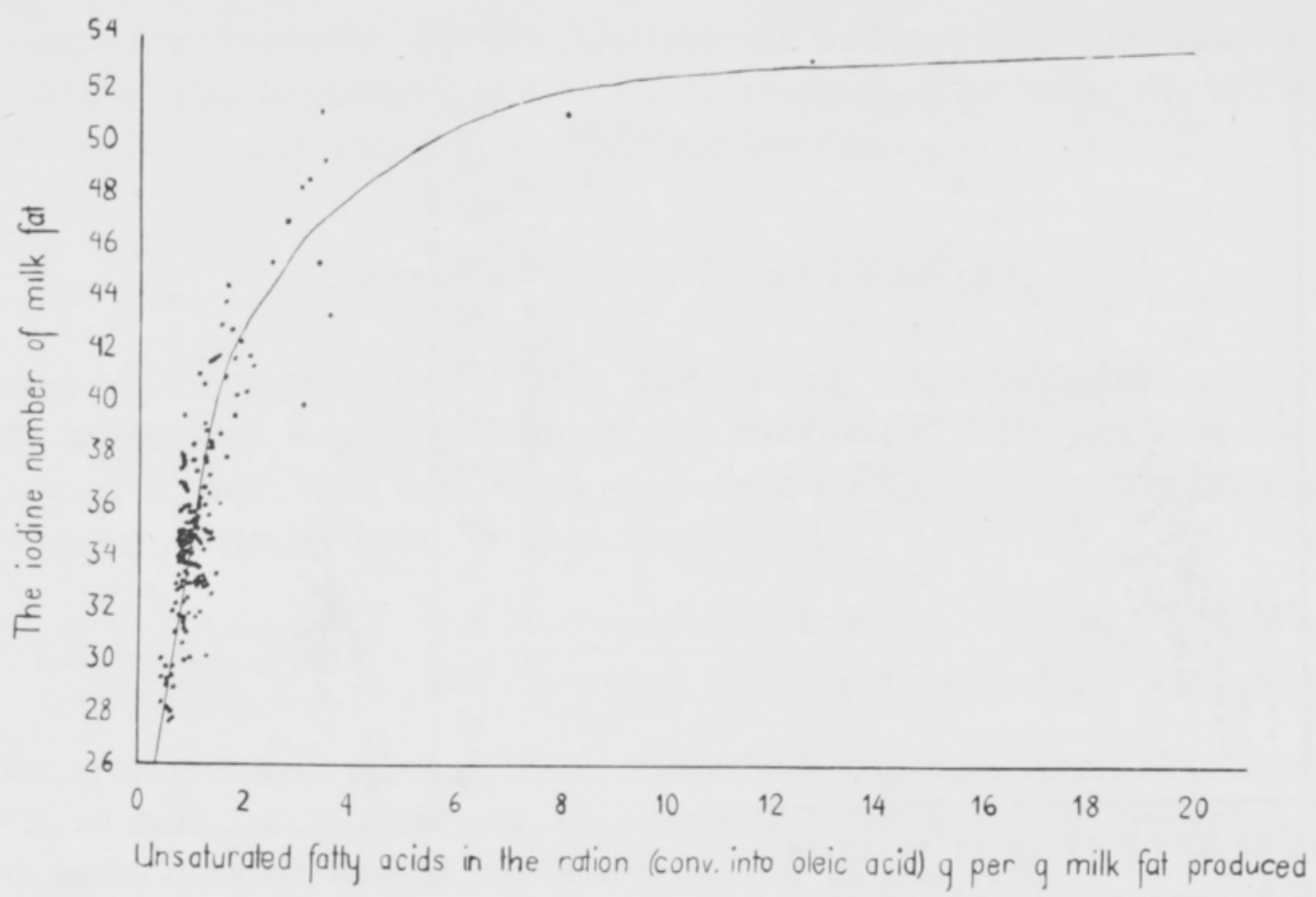

Fig. 1. The dependence of the iodine number on the ratio $\frac{\text { U. F. A. consumed }}{\text { M. F. secreted }}$

was the most variable, and the effect of this ratio was studied first. When the ratio was plotted against the iodine number (Fig. 1) it was found that the effect appeared to be curved linear and could be fairly well expressed by the following formula:

$$
\frac{\text { U.F.A. consumed }+k_{1}}{\text { M.F. secreted }+k_{2}}
$$

The approximate value of $\mathrm{k}_{1}$ appeared to correspond to c. 1000 and that of $\mathrm{k}_{2}$ to c. 1500 , as can be seen from fig. 2 .

It was assumed that the actual value of $k_{1}$ is related to the rate of formation of U.F.A. in the body and $k_{2}$ to the rate of destruction of these acids in the body, both of which might well be in proportion to the size of the animal. So, $\mathrm{k}_{1}$ and $\mathrm{k}_{2}$ were considered to be multiples of the live weights of the animals. The average live weight was c. $500 \mathrm{~kg}$ and hence $\mathrm{k}_{1}=2 \times \mathrm{LW}$ and $\mathrm{k}_{2}=3 \times \mathrm{LW}$.

In addition it was calculated that the amount of U.F.A. mobilized by each Scandinavian feed unit underfeeding $\left(\mathrm{Sc} . \mathrm{fu}_{u}\right)$ was equivalent to c. $200 \mathrm{~g}$ of oleic acid. Based on this calculation, one Scandinavian feed unit overfeeding $\left(\mathrm{Sc} . \mathrm{fu}_{o}\right)$ showed statistically a depression of iodine number equivalent to the effect of c. $60 \mathrm{~g}$ milk fat secreted.

Hence the combined effects of all the variates studied could be expressed by the approximate formula:

$$
\begin{aligned}
& \text { U.F.A. consumed } \mathrm{g} / \text { day }+200 \cdot \mathrm{Sc} . \mathrm{fu}_{u}+2 \mathrm{~L} . \mathrm{W} \\
& \text { M.F. secreted } \mathrm{g} / \text { day }+60 \cdot \mathrm{Sc} . \mathrm{fu}_{o}+3 \mathrm{~L} . \mathrm{W}
\end{aligned}
$$




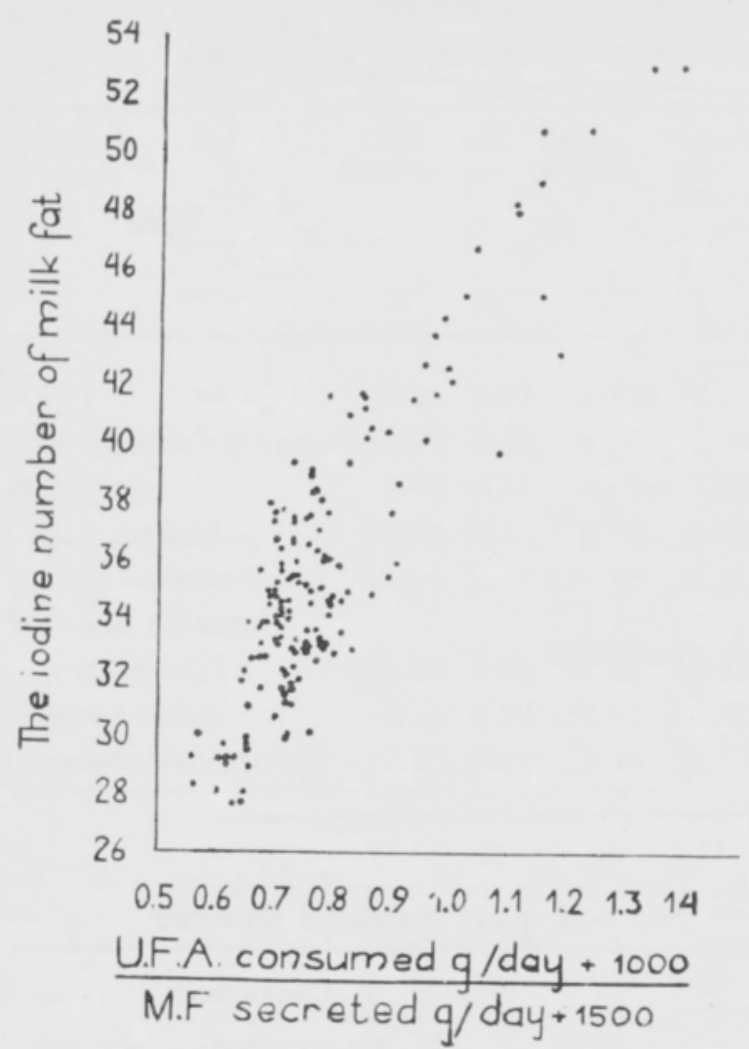

Fig. 2. The dependence of the iodine number

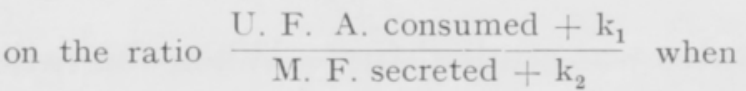
$\mathrm{k}_{1}=1000$, and $\mathrm{k}_{2}=1500$.

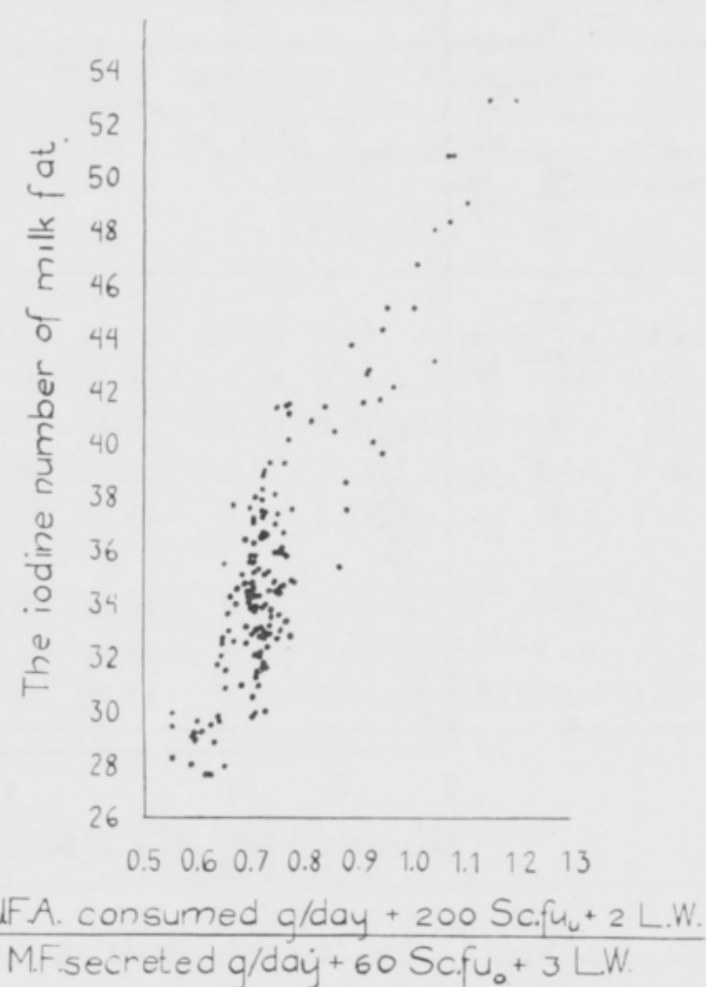

Fig. 3. The hypothetical dependence of the iodine number on all variates studied.

The values calculated according to this formula and plotted against the iodine numbers are presented in fig. 3. The coefficient of correlation is fairly high $(\mathrm{r}=$ $+0.8723)$. The coefficient of regression was found to be $\mathrm{R}_{\mathrm{y}}^{\mathrm{x}}=38.5188$, and the approximate effect of diet on the I.N. of milk fat is given by the following formula:

$$
\mathrm{I.N} .=6.7+38.5 \cdot \frac{\text { U.F.A. consumed } \mathrm{g} / \text { day }+200 \times \mathrm{Sc} . \mathrm{fu}_{u}+2 \mathrm{~L} . \mathrm{W} .}{\text { M.F. secreted } \mathrm{g} / \text { day }+60 \times \mathrm{Sc} . \mathrm{fu}_{o}+3 \mathrm{~L} . \mathrm{W} .}
$$

\section{Discussion}

In figures $1-3$ only the results obtained from the actual feeding trials are included. The figures obtained during the grazing season and when feeding sugar beet tops appeared to confirm these results. As however, the exact amounts of these feeds consumed were not determined, these data had to be excluded from the calculations.

The material presented here is limited. The variations in the total amounts of U.F.A. in the ration are mainly caused by linseed fat, which represents just one type of unsaturated fat only. So, the regressions obtained with some other unsaturated fats and oils might be different. Very many analytical and experi- 
mental data are, however, already available at research institutes elsewhere, and the validity of this hypothesis can be easily re-checked by using the old material. The authors hope that this will be done somewhere.

\section{Summary and conclusions}

Based on the data collected from two feeding trials conducted with Ay-cows fed with linseeds as a principal source of unsaturated fatty acids in the ration, the following formula was computed showing the effect of the diet on the iodine number (I.N.) of the milk fat in these experiments:

$$
\text { I.N. }=6.7+38.5 \cdot \frac{\text { U.F.A. consumed, g/day }+200 \times \mathrm{Sc} . \mathrm{fu}_{u}+2 \times \mathrm{L} . \mathrm{W} .}{\text { M.F. secreted, g/day }+60 \times \mathrm{Sc} . \mathrm{fu}_{o}+3 \times \mathrm{L} . \mathrm{W} .}
$$

where unsaturated fatty acids (U.F.A.) in feed are expressed as an oleic acid equivalent, M.F. = milk fat (g./day), Sc. $\mathrm{fu}_{u}=$ Scandinavian feed units underfed, $\mathrm{Sc}_{\mathrm{fu}} \mathrm{fu}_{\mathrm{o}}=$ Sc. feed units overfed, and L.W. = live weight in kilograms.

\section{REFERENCES}

(1) Anantakrishnan, C. P. \& Bhaleravo, V. R. \& Paul, T. M., 1948. The glyceride composition of milk fat. Arch. Biochem. 18: $35-40$.

(2) Balch, C. C. \& Balch, D. A. et al. 1952. Studies on the secretion of milk of low fat content by cows on diets low in hay and high in concentrates. 1. The effect of variation in the amount of hay. J. Dairy Res. 19: $39-50$.

(3) Bartley, E. E. \& Zaletel, J. H. et al. 1951. The relationship of stage of lactation, pasturage and environmental temperature to the degree of unsaturation of cow milk fat. J. Dairy Sci. 34: $536-547$.

(4) Bergman, I. \& Joost, K. 1952. Fettets jodtal i svensk mejerimjölk, dess inverkan på smörets konsistens jämte förslag till mjölkens betalning efter jodtal. Mej.tekn. medd. 2-3: $23-31,61-65$.

(5) Beythien, A. 1931. Laboratoriumsbuch für den Nahrungsmittelchemiker. Dresden (Ref. 1931, Hansson, N. \& Olofsson, N. 1931.)

(6) Breirem, K. 1946. Sildemel norsk fôr til norske husdyr. Landbr. høgsk. inst. husdyrern. fôringsl. 48. Saertr., $19 \mathrm{p}$.

(7) Brouwer, E. \& Dijkstra, N. D. \& Frens, A. M., 1943. Over de bijvoedering van het melkvee in de weide met copra, voederbieten en aardappelen, in verband met de stevigheid van de geproduceerde boter. Versl. rijkslandb. proefst. 's grav., p. 347-406.

(8) Brouwer, E. \& Frens, A. M. 1938. Voederproeven omtrent het joodgetal van het botervet en de stevighed van de boter in den winter en in den zomer. Versl. ver, proefzuiv. Hoorn (Verslag over het jaar 1937), p. 49-110.

(9) Brozzetti, P. 1947. Contributo sperimentale allo studio dell' influenza esercitata dall' alimentazione su alcuni indici del burro. [Influence of feed on the physical and chemical properties of butter]. Mondo latte (December), p. 11-15.

(10) Cox, G. A. \& Mc Dowall, F. H. 1948. The properties of New Zealand butters and butterfats. I. Iodine, Reichert and saponification values and softenings points of monthly samples of butterfats from nine commercial factories over four years. J. Dairy Res. 15: $377-386$. 
(11) Davidov, R. B. \& Aristova, V. P., 1952. [The effect of linseed cake in the ration of cows on the composition and properties of butter.] Sovetsk. zootekhn. 7: $53-61$.

(12) Dijkstra, N. D., 1950. The feeding value of stubble - rapes (late turnips). Versl. landb. onderzoek. Minist. landb.'s grav. 56: 39 .

(13) Eckles, C. H. \& Palmer, L. S. 1916. Influence of plane of nutrition of the cow upon the composition and properties of milk and butterfat. Mo. Agr. Expt. Sta., Res. Bull. 24: 1-35 (Ref. Chem. Abstr. 10: 2919.)

(14) Eskedal, H. W. 1953. Fedfattigt og fedrigere kraftfoder til melkekøer. Fors.lab. København ber. $268: 45$.

(15) Frens, A. M., 1949. The effects on butterfat of pasture grass and grassland - products. Rep. XII Int. Dairy Congr. Stockholm 6: $9-28$.

(16) Frye, J. B., Jr. 1946. Influence of soybeans on the flavour of milk, cream, and butter, and on the body and texture of butter. Iowa Sta. Coll. J. Sci. 21: 24-28.

(17) Frye, J. B., Jr. \& Connon, C. Y. \& Bird, E. M., 1950. The influence of cracked soybeans and other factors upon flavor of milk and the iodine value of milk fat. J. Dairy Sci. $33: 205-215$.

(18) - - 1950. The relationship among cracked soybeans fed, barn temperature and the degree of unsaturation of milk fat. J. Dairy Sci. 33: 257-266.

(19) Haglund, E. \& Wode, G. \& Olsson, I. 1930. Undersökningar över det svenska smörets konsistens. Centr.anst. förs.verks. jordbr.omr. Medd. 387. Mej.avd. 41.

(20) Hansen, A. P. \& Steensberg, V. 1930. Nogle fodermidlers indflydelse paa smorrets konsistens m. m. 134. Ber. fors.lab.

(21) Hansson, N. \& Olofsson, N. 1931. Fortsatta undersökningar angående de olika fodermedlens inflytande på smörets konsistens. Centr.anst. förs.verk. jordbr. omr. Medd. 394. Stockholm.

(22) Henriques, V. \& Hansen, C. 1899. Recherches sur la formation de la graisse dans l'organisme par l'alimentation grasse intensive. K. danske vidensk. selsk. forh. 4.

(23) Hietaranta, M. 1953. Ruokinnan vaikutuksesta maitorasvan koostumukseen ja voin kiinteyteen. Karjantuote 36: $38-41,65-68$.

(24) Hilditch, T. P. 1949. The chemical constitution of natural fats. II ed. Repr. New York.

(25) Hostettler, H. \& Flückiger, E. \& Lehmann, W. 1954. Effect of feeding beet on the quality of milk and butter. Schweiz. Milchztg. 80: 639-641.

(26) Jaegum, E. \& Hedemann, H. 1953. The addition of ground linseed to the winter rations of Jersey cows. Maelkeritidende 66: $753-754$.

(27) JARL, F. 1949. Olika näringsämnens samt kroppsviktsförändringens inflytande på mjölkfettets jodtal. XII Int. mej.kongr. Stockholm 1: $92-98$.

(28) Lönnfors, M. 1954. Bidrag till kännedomen om utfodringens inverkan på smörfettets konsistens, Reichert-Meissl- och jodtal. Master's thesis.

(29) Mattsson, S. 1949. Di- och triensyror i smör och deras inflytande på smörets oxidation. 1. Bestämningsmetodik och preliminära resultat. Stat. mej.förs. Medd. 26.

(30) Mattsson, S. \& Thomé, K. E. \& Swartling, P. 1951. Di- och triensyror i smör och deras inflytande på smörets oxidation. 2. Oxidation av smörfett av olika sammansättning. Ibid. 33.

(31) Moghul, H. K. \& Singh. I. P. \& Paul, T. M. \& Anantakrishnan, C. P. 1948. Feed effects on the composition of milk fat. Indian J. Dairy Sci. 1: 111-116.

(32) Mulder, H. 1953. The consistency of butter. Foodstuffs, their plasticity, fluidity and consistency, p. 91-123. (Ed. Scott Blair, G. W.) Amsterdam.

(33) Olsson, T. 1948. Några exempel på inverkan av gräddens behandling på smörets hårdhet och konsistens. Stat. mej.förs. Medd. 24.

(34) Patel, B. M. \& Ray, S. C. 1949. Studies on cotton seed feeding to milk animals. 2. The quality of ghee from buffalo fed on cotton seed in combination with dry or green fodder. Indian J. Dairy Sci 2: $30-38$.

(35) Paul, T. M. \& Anantakrishnan, C. P. 1949. Nature of end-lactation milk fat. Indian J. Dairy Sci. 2: $58-64$. 
(36) SANdelin, A. 1936. Huru inverkar AIV-fodret på smörets kvalitet? Jordbr.tekn. för. Särtr.ser. 40.

(37) Sмith, J. A. B. \& Dastur, N. N. 1938. Studies in the secretion of milk fat. 2. The effect of inanition on the yield and composition of milk fat. Biochem. J. 32: 1868-1876.

(38) Steensberg, V. 1936. Kvalitet og Fodring. København.

(39) StorgÅRDS, T. 1934. Tutkimuksia suomalaisen voin kiinteysvirheistä. Valt.maitotal.koel. julk. 1.

(40) —- 1939 a. Rehurasvan vaikutuksesta voirasvan laatuun, Karjatalous 13-14, 15. Erip.

(41) —— 1939 b. Tutkimuksia rehurasvan vaikutuksesta voirasvan laatuun. Valt. maitotal.kcel. julk 4.

(42) —— 1939 c. Om foderfettets inflytande på mjölkens fetthalt och mjölkfettets sammansättning. Särtr. Lantm.bl.

(43) Sutton, T. S. \& Brown, J. B. \& Johnston, E. W. 1932. The effect of corn oil on milk and butterfat production and on the composition of butterfat in the dairy cow. J. Dairy Sci. 15: $209-211$.

(44) Williamis, N. K. \& Cannon, C. Y. \& Espe, D. L. 1943. A soybean and silage ration for dairy cows J. Dairy Sci. 26: $241-249$.

(45) ÖRBORN, A. 1944. Vallfodrets inverkan på mjölkens kvalitet. Sver. utsädesför. tidskr. 53: 327-331.

S E L O T U S :

KAAVA MAITORASVAN JODILUVUN ARVIOIMISEKSI RUOKINNAN NOJALLA

Pellervo SaArinen ja Marita Lönnfors

Yliopiston kotieläintieteellinen laitos, Viikin koetila, Malmi.

Otsakkeessa mainitun asian selvittämiseksi Viikin koetilalla on suoritettu kaksi ruokintakoetta käyttäen jodiluvun vaihtelujen aikaansaamiseksi mm. kuumana rouhittuja pellavansiemeniä ruokinnassa. Ruokinnan vaikutus maitorasvan jodilukuun voidaan saadun koeaineiston mukaan likimääräisesti ilmaista seuraavalla kaavalla:

$$
\text { Jodiluku }=6.7+38.5 \cdot \frac{\text { Tyydytt. rasvah. rehussa } \mathrm{g} / \mathrm{pv}+200 \cdot \mathrm{ry}_{a}+\cdot 2 \cdot \text { elop. }}{\text { Maitorasvaa } \mathrm{g} / \mathrm{pv}+60 \cdot \mathrm{ry}_{y}+3 \cdot \text { elop. }}
$$

Kaavassa on rehun tyydyttämättömien rasvahappojen määrä ilmaistu öljyhapoksi laskettuna, ry $a$ $=$ aliruokinnan määrä rehuyksiköissä, $r_{y}=$ yliruokinnan määrä rehuyksiköissä ja elóp. = elopaino kiloissa. 